RJOAS, 7(103), July 2020

DOI 10.18551/rjoas.2020-07.01

\title{
ROOTSTOCKS AND PLANT GROWTH REGULATOR TO PROMOTE GROWTH OF GRAPEVINE SEEDLING CV. PRABU BESTARI
}

\author{
Aji Titistyas Gusti*, Sugiyatno Agus \\ Indonesian Citrus and Subtropical Fruits Research Institute, East Java, Indonesia \\ *E-mail: titistyasgusti@pertanian.go.id
}

\begin{abstract}
Good quality seedling is the key to achieve potential of production and quality of fruit. Cuttingsgrafting is a propagation method applied to obtain good quality plants, ones that have strong roots and are resistant to disease. This study aimed to describe the effect of rootstocks and plant growth regulator in promoting growth of grapevine seedling cv. Prabu Bestari. The study was conducted in Tlekung Experimental Garden, East Java. It employed factorial Completely Randomized Design with 2 factors and 3 replications. The first factor was the rootstock variation that consisted of 3 levels, namely Banjarsari 30, Banjarsari 5, and Banjarsari 8. The second factor was plant growth regulator consisting of 5 levels, namely Rootone-F, Shallot Extract, Young Coconut Water, Java Turmeric Extract, and Control. The findings showed that Banjarsari 30 as rootstock and Rootone-F as growth regulator gave the best response in growth of grapevine seedling cv. Prabu Bestari.
\end{abstract}

\section{KEY WORDS}

Rootone-F, cutting, grafting, root growth.

Indonesia is rich in biodiversity as well as various types of agro-ecosystems and agroclimate that have positive impact towards tropical and subtropical fruit commodities. Grape (Vitis vinifera L.) is an introduced plant species widely cultivated in East Java. Red Prince grape came from Australia and in Indonesia, the grape is known as Prabu Bestari. This variety is cultivated in both East Java and Bali. Prabu Bestari grape is reddish and shiny, slightly oval and sweet. One grapevine can produce between 10 and $30 \mathrm{~kg}$ of grapes. Furthermore, this grape can potentially be used as raw material for fruit juice (Andrini, 2006; Krismawati and Prahardini, 2011). Prabu Bestari grape business is quite promising in which the ratio between benefit and cost is 1.85 (Maulidah and Pratiwi, 2010).

Successful grapevine cultivation begins with good quality of seeds. The most frequent propagation method for grapevines is stem cuttings with 2-3 healthy buds, with success rate of more than $80 \%$ (Krismawati and Prahardini, 2011). In addition to cuttings, grafting is another propagation method widely practiced; grafting is to join grapevine's rootstock and its young shoots. Taking into account of the advantages and disadvantages of both techniques, experts in agriculture develop a propagation technique for grapevines by combining between cuttings (as rootstock) and grafting (as scion), this technique is known as cuttings-grafting. Some advantages of cuttings-grafting are using plants that have thick roots as rootstocks so that the plants can be planted firmly as well as promoting growth of fruit and production (Sugiyatno and Sukadi, 2017). It is important to pay a close attention to lower and upper stem compatibility. Sudjijo (2009) stated that compatibility between the rootstock and upper stem is the criterion for good grafting seed. Successful grafting is characterized by the joint between the upper and lower stem and growth rate of the seed.

Growth regulators are applied to promote growth of plant. Plant growth regulator (PGR) is a group of chemicals used to control plant growth or other physiological functions of the plant (Sharma, 2015). Based on its source, PGR can be divided into natural and synthetic PGR. Natural PGR is available in the nature and derived from organic materials such as coconut 
water, dairy cow urine, green bean sprout extract, shallot tuber extract, bamboo shoot extract, and banana weevil extract (Leovici et al., 2014; Kurniati et al., 2017). As natural PGR, 20\% of shallot extract was able to accelerate bud initiation time and increase length of grapevine roots (Diana, 2014), while 50\% of shallot extract promoted length of shoots and number of leaf of grapevine (Utami et al., 2016). Besides shallot extract, it is reported that $20 \%$ of young coconut water promoted growth and accelerated bud initiation and all variables of Alphonso Lavalle grapevine vegetative growth (Wahyuningtyas et al., 2017). Curcumin extracted from turmeric has a fungicidal effect towards phytopathogenic fungi on a greenhouse scale (Kim et al., 2003) and in vitro culture (Upendra et al., 2011). However, none of the previous related studies discussed application of curcumin as a growth regulator.

Cutting-grafting method can be developed to accelerate production process and increase quality of Prabu Bestari grapevine seedling. This study discussed the effect of rootstocks and plant growth regulator in increasing Prabu Bestari grapevine growth.

\section{METHODS OF RESEARCH}

The study was conducted from March to June, 2016 in Tlekung Experimental Garden, Indonesian Citrus and Subtropical Fruits Research Institute, located at $900 \mathrm{~m}$ above sea level. The materials were Banjarsari 30, Banjarsari 5, and Banjarsari 8 grapevine stems for rootstock and Prabu Bestari grapevine stems for scion. These materials were collected from Banjarsari Experimental Garden, Indonesian Citrus and Subtropical Fruits Research Institute, located in Probolinggo, East Java. The growth regulating substances were Rootone-F, shallot extract, young coconut water, and java turmeric extract. The planting media were mixture of river sand deposits, manure, and husk with ratio of 2: 1: 1 . The media were placed in a $13 \mathrm{~cm} \times 20 \mathrm{~cm}$ polybag. Fungicide was applied onto the media 3 days before planting.

The experiment began by preparing the rootstock and upper stem for cuttings. The brown and woody branches were cut into a $20-25 \mathrm{~cm}$ long branch (3-4 buds) for the rootstock and a 5$10 \mathrm{~cm}$ long branch (1 bud) for the upper stem. Grafting was conducted by making a cut of 2-3 $\mathrm{cm}$ in the middle of the branch and slashing the rootstock for about 2-3 cm. The following procedure was to insert the upper stem cutting to rootstock and wrap them tightly with plastic. The upper stem was dipped into paraffin solution to reduce evaporation. Before planting, the cutting-grafting was dipped in PGR solution, namely Rootone-F paste, $10 \%$ shallot extract, $10 \%$ coconut water and $10 \%$ java turmeric extract. Shallot and java turmeric were put into a blender and sieved to get the shallot extract and java turmeric extract. The extract was a stock solution with concentration of $100 \%$. Every $100 \mathrm{ml}$ of the stock solution was diluted with $900 \mathrm{ml}$ of water to make a solution with concentration of $10 \%$. The young coconut water consisted of $100 \mathrm{ml}$ of young coconut water and $900 \mathrm{ml}$ of water. After being soaked in the PGR solution, the cuttinggrafting was planted in polybags that were arranged on a shelf and covered with paranet.

The study employed factorial Completely Randomized Design where the first factor was the rootstock and the second factor was growth regulator. The rootstock consisted of 3 levels, namely Banjarsari 30 , Banjarsari 5 , and Banjarsari 8 , while the growth regulator consisted of 5 levels, namely Rootone-F, shallot extract, young coconut water, java turmeric extract, and control (without PGR). There were 15 combinations in total and each combination was replicated 3 times. Each combination involved 4 plants making 180 plants in total. The data analysis method was F-test. When the result of the F-test was significant, Duncan's Multiple Range Test with $95 \%$ level of confidence was conducted. Statistical software used to analyze the data was SAS version 9.0 .

The variables observed were bud bursting time, shoot length, number of leaves, shoot diameter, number of roots, root length, root weight, and percentage of successful grafting (grow and germinate). Plant growth observation was carried out every 2 weeks until 12 weeks after 
planting (WAP). Observation of bud bursting time was carried out every day, while root length, root weight, and percentage of successful grafting were observed at the end of the study.

\section{RESULTS OF STUDY}

Observation towards growth of the grapevine showed that the rootstocks caused a significant increase in the shoot length from week 6 . In addition, the growth regulator increased the shoot length, and number, length and weight of the roots starting from week 4 . Interaction between the rootstocks and growth regulator increased the shoot length starting from week 4 . However, neither the rootstocks nor growth regulator application and their interaction influence percentage of suc scessful grafting, bud bursting time, number of leaves, and shoot diameter.

Without the growth regulator, percentage of successful grafting of Prabu Bestari grapevine with rootstocks of Banjarsari 30, Banjarsari 5 and Banjarsari 8 were $75.00 \%, 75.00 \%$ and $83.00 \%$, respectively. Application of plant growth regulators changed the percentage of successful grafting into $77.25 \%, 91.50 \%$, and $79.00 \%$. Application of plant growth regulators combined either with Banjarsari 30 or Banjarsari 5 rootstocks help increasing percentage of successful grafting (Table 1).

Table 1 - Percentage of successful grafting and bud bursting time of Prabu Bestari grapevine with different rootstocks and PGR

\begin{tabular}{ccc}
\hline Treatments & Percentage of Successful Grafting & Bud Burst (Days After Planting) \\
\hline Rootstocks & & $18.38 \pm 7.66$ \\
Banjarsari 30 & $76.67 \pm 17.59$ & $20.68 \pm 7.00$ \\
Banjarsari 5 & $88.33 \pm 18.58$ & $23.88 \pm 6.71$ \\
Banjarsari 8 & $80.00 \pm 21.55$ & $18.56 \pm 8.05$ \\
PGR & $77.78 \pm 26.35$ & $23.76 \pm 4.67$ \\
Rootone-F & $86.11 \pm 13.18$ & $20.90 \pm 9.39$ \\
Shallot & $86.11 \pm 18.16$ & $19.78 \pm 8.13$ \\
Coconut water & $80.56 \pm 20.83$ & $21.91 \pm 6.07$ \\
Java turmeric & $77.78 \pm 19.54$ & $\mathrm{~ns}$ \\
\hline Control (No PGR) & $\mathrm{ns}$ & \\
\hline Interaction & &
\end{tabular}

Description: ns: not significant.

Table 2 - Shoot length of Prabu Bestari grapevine seedling with different rootstocks and PGR

\begin{tabular}{|c|c|c|c|c|c|c|}
\hline \multirow{2}{*}{ Treatment } & \multicolumn{6}{|c|}{ Plant Age (Weeks After Planting) } \\
\hline & 2 & 4 & 6 & 8 & 10 & 12 \\
\hline & \multicolumn{6}{|c|}{ Shoot Length $(\mathrm{cm})$} \\
\hline Rootstocks & & & & & & \\
\hline Banjarsari 30 & $0.72 \pm 1.17$ & $3.07 \pm 2.25$ & $4.45 \pm 1.79 \mathrm{a}$ & $6.18 \pm 2.60 \mathrm{a}$ & $8.51 \pm 3.15 \mathrm{a}$ & $10.86 \pm 3.64 \mathrm{a}$ \\
\hline Banjarsari 5 & $0.93 \pm 0.81$ & $2.42 \pm 1.27$ & $3.70 \pm 1.43 a b$ & $5.32 \pm 1.56 b$ & $7.31 \pm 1.85 b$ & $9.57 \pm 2.27 b$ \\
\hline $\begin{array}{c}\text { Banjarsari } 8 \\
\text { PGR }\end{array}$ & $0.83 \pm 0.77$ & $2.20 \pm 1.18$ & $3.63 \pm 1.04 b$ & $5.04 \pm 1.07 b$ & $6.81 \pm 1.04 b$ & $8.62 \pm 0.88 \mathrm{c}$ \\
\hline Rootone-F & $1.36 \pm 1.25$ & $3.95 \pm 2.14 \mathrm{a}$ & $5.00 \pm 1.44 \mathrm{a}$ & $7.33 \pm 2.13 \mathrm{a}$ & $9.77 \pm 2.63 \mathrm{a}$ & $12.24 \pm 3.09 \mathrm{a}$ \\
\hline Shallot & $1.15 \pm 0.87$ & $3.11 \pm 2.01 \mathrm{ab}$ & $4.75 \pm 1.98 \mathrm{a}$ & $6.20 \pm 2.36 b$ & $8.49 \pm 2.76 b$ & $10.95 \pm 3.31 b$ \\
\hline Coconut water & $0.45 \pm 0.61$ & $2.16 \pm 0.49 \mathrm{bc}$ & $3.52 \pm 0.82 b$ & $4.50 \pm 0.39 \mathrm{~cd}$ & $6.39 \pm 0.60 \mathrm{c}$ & $8.50 \pm 0.73 c$ \\
\hline Java turmeric & $0.56 \pm 0.66$ & $1.97 \pm 0.71 \mathrm{bc}$ & $3.42 \pm 0.85 b$ & $5.25 \pm 0.82 c$ & $7.00 \pm 0.85 c$ & $8.84 \pm 0.63 c$ \\
\hline Control (No PGR) & $0.62 \pm 0.87$ & $1.61 \pm 1.19 c$ & $2.94 \pm 0.90 \mathrm{~b}$ & $4.29 \pm 1.11 \mathrm{~d}$ & $6.08 \pm 1.25 c$ & $7.86 \pm 1.21 \mathrm{c}$ \\
\hline Interaction & ns & $\star \star \star$ & $\star \star$ & $\star \star *$ & ** & ** \\
\hline
\end{tabular}

Description: Values followed by the same letter at the same column were not significantly different based on DMRT with 95\% level of confidence.; ns: not significant; ${ }^{* *}$ : significant based on DMRT with 99\% level of confidence.

Buds of Prabu Bestari grapevine with rootstock of either Banjarsari 30, Banjarsari 5, or Banjarsari 8 combined without PGR bursted at 23.89, 16.33, and 25.50 days after planting 
(DAP) consecutively. With PGR, their bud bursted at 17.00, 21.77, and 23.47 DAP respectively. Combination of PGR either with Banjarsari 30 or Banjarsari 8 rootstocks accelerated bud burst (Table 1).

The rootstocks, application of plant growth regulator and combination between the two have positive influence towards the length of Prabu Bestari grapevine shoot. Banjarsari 30 as rootstock and Rootone-F as PGR resulted in the longest shoot in the 8, 10, and 12 WAP (Table 2). Banjarsari 30 and the shallot extract grew the shoot up to $15.00 \mathrm{~cm}$ in the 12 WAP; however, the result does not have significant difference from those of the combination between Rootone- $F$ and Banjarsari 30 or Banjarsari 5; the last two combinations grew the shoot to $14.76 \mathrm{~cm}$ and $13.48 \mathrm{~cm}$, respectively (Table 3).

Table 3 - Interaction between different rootstocks and PGR towards shoot length of Prabu Bestari grapevine seedling

\begin{tabular}{|c|c|c|c|c|c|c|c|c|c|c|c|}
\hline \multicolumn{2}{|c|}{ Treatment } & \multicolumn{10}{|c|}{ Plant Age (Weeks After Planting) } \\
\hline Rootstocks & PGR & 4 & & 6 & & 8 & & 10 & & 12 & \\
\hline \multirow{6}{*}{$\begin{array}{c}\text { Banjarsari } \\
30\end{array}$} & Rootone-F & $\begin{array}{c}6.33 \pm \\
0.47\end{array}$ & a & $\begin{array}{c}6.27 \pm \\
0.53\end{array}$ & $a$ & $\begin{array}{c}8.91 \pm \\
0.66\end{array}$ & a & $\begin{array}{c}11.91 \pm \\
1.44\end{array}$ & $\mathrm{a}$ & $\begin{array}{c}14.76 \pm \\
0.84\end{array}$ & a \\
\hline & Shallot & $\begin{array}{c}4.73 \pm \\
0.83\end{array}$ & $\begin{array}{l}a \\
b\end{array}$ & $\begin{array}{c}6.42 \pm \\
0.32\end{array}$ & a & $\begin{array}{c}9.15 \pm \\
1.20\end{array}$ & a & $\begin{array}{c}11.90 \pm \\
1.50\end{array}$ & a & $\begin{array}{c}15.00 \pm \\
1.75\end{array}$ & a \\
\hline & Coconut water & $\begin{array}{c}2.00 \pm \\
0.20\end{array}$ & $\begin{array}{l}c \\
d\end{array}$ & $\begin{array}{l}3.64 \pm \\
1.09\end{array}$ & $\begin{array}{l}b \\
c\end{array}$ & $\begin{array}{c}4.37 \pm \\
0.69\end{array}$ & $\mathrm{~cd}$ & $\begin{array}{c}6.75 \pm \\
0.63\end{array}$ & b & $\begin{array}{c}9.03 \pm \\
0.80\end{array}$ & b \\
\hline & Java turmeric & $1.53 \pm$ & c & $3.58 \pm$ & b & $5.34 \pm$ & $b c$ & $7.37 \pm$ & $h$ & $9.08 \pm$ & $b$ \\
\hline & Contol & 0.71 & d & 0.98 & c & 0.24 & & 0.60 & 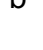 & 0.35 & \\
\hline & $\begin{array}{c}\text { Control (No } \\
\text { PGR) }\end{array}$ & $\begin{array}{c}0.75 \pm \\
0.65\end{array}$ & d & $\begin{array}{c}2.35 \pm \\
0.46\end{array}$ & C & $\begin{array}{c}3.10 \pm \\
0.42\end{array}$ & d & $\begin{array}{c}4.59 \pm \\
0.35\end{array}$ & C & $\begin{array}{c}6.40 \pm \\
0.39\end{array}$ & $\mathrm{C}$ \\
\hline \multirow{8}{*}{$\begin{array}{l}\text { Banjarsari } \\
5\end{array}$} & Rootone-F & $\begin{array}{c}3.30 \pm \\
0.70\end{array}$ & $\begin{array}{l}b \\
c\end{array}$ & $\begin{array}{l}5.34 \pm \\
0.25\end{array}$ & $a$ & $8.19 \pm$ & a & $10.59 \pm$ & $\mathrm{a}$ & $13.48 \pm$ & a \\
\hline & Shallot & $2.23 \pm$ & c & $3.86 \pm$ & b & $4.68 \pm$ & $b c$ & $6.69 \pm$ & $b$ & $9.12 \pm$ & $b$ \\
\hline & & 2.75 & d & 2.48 & c & 0.90 & & 1.17 & & 1.84 & \\
\hline & Coconut water & $2.49 \pm$ & c & $3.41 \pm$ & b & 4.60 & bc & $6.36 \pm$ & $h$ & $8.35 \pm$ & $h_{1}$ \\
\hline & & 0.53 & d & 0.91 & c & \pm 0.09 & d & 0.36 & 10 & 0.81 & $\mathbf{D}$ \\
\hline & Java turmeric & $2.05 \pm$ & C & $2.68 \pm$ & C & $4.38 \pm$ & $\mathrm{cd}$ & $6.07 \pm$ & b & $8.13 \pm$ & b \\
\hline & Control (No & $2.00 \pm$ & c & $3.20 \pm$ & $r$ & $4.77 \pm$ & he & $6.86 \pm$ & $h$ & $8.76 \pm$ & $h_{1}$ \\
\hline & PGR) & 0.59 & d & 1.03 & $c$ & 0.76 & JC & 0.59 & 0 & 0.48 & 0 \\
\hline \multirow{8}{*}{$\begin{array}{c}\text { Banjarsari } \\
8\end{array}$} & Rootone-F & $2.22 \pm$ & c & $3.40 \pm$ & b & $4.90 \pm$ & bc & $6.82 \pm$ & $b$ & $8.50 \pm$ & b \\
\hline & & 1.98 & d & 1.23 & c & 1.99 & 20 & 1.84 & 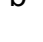 & 1.60 & \\
\hline & Shallot & $\begin{array}{c}2.36 \pm \\
139\end{array}$ & $\begin{array}{c}c \\
d\end{array}$ & $\begin{array}{c}3.95 \pm \\
177\end{array}$ & b & $\begin{array}{l}4.77 \pm \\
070\end{array}$ & bc & $\begin{array}{c}6.87 \pm \\
0.82\end{array}$ & $b$ & $\begin{array}{c}8.74 \pm \\
079\end{array}$ & b \\
\hline & Coconut wats & $2.00 \pm$ & c & $3.51 \pm$ & b & $4.52 \pm$ & bc & $6.05 \pm$ & b & $8.12 \pm$ & $h$ \\
\hline & Coconut water & 0.62 & d & 0.77 & c & 0.28 & d & 0.73 & c & 0.41 & b \\
\hline & Java turmeric & $2.32 \pm$ & c & $4.02 \pm$ & b & $6.02 \pm$ & $b$ & $7.54 \pm$ & $b$ & $9.31 \pm$ & $b$ \\
\hline & Java tumeric & 0.37 & d & 0.73 & c & 0.73 & & 0.73 & 0 & 0.47 & T \\
\hline & $\begin{array}{l}\text { Control (No } \\
\text { PGR) }\end{array}$ & $\begin{array}{c}2.07 \pm \\
1.80\end{array}$ & $\begin{array}{l}c \\
d\end{array}$ & $\begin{array}{c}3.26 \pm \\
1.08\end{array}$ & c & $\begin{array}{l}5.00 \pm \\
0.96\end{array}$ & bc & $\begin{array}{l}6.78 \pm \\
0.87\end{array}$ & b & $\begin{array}{l}8.42 \pm \\
0.80\end{array}$ & b \\
\hline
\end{tabular}

Description: Values followed by the same letter at the same column were not significantly different based on DMRT with $95 \%$ level of confidence.

Application of the growth regulators resulted in number of leaves of Prabu Bestari seedling in the 12 WAP were 11.52, 12.51, and 12.21, consecutively. Without the growth regulator, number of leaves of the Prabu Bestari grapevine with Banjarsari 30, Banjarsari 5, and Banjarsari 8 rootstocks in the 12 WAP were 10.33,13.00, and 10.11, respectively. In general, application of growth regulator either with Banjarsari 30 or Banjarsari 8 rootstocks increased the number of Prabu Bestari grapevine seedlings leaves (Figure 1). 


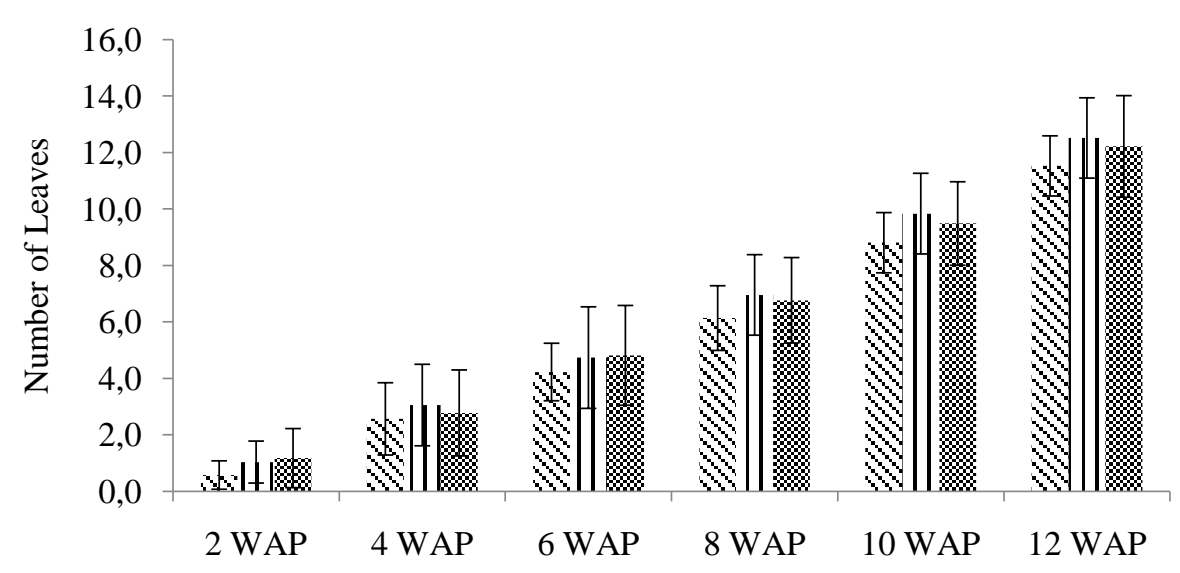

Plant Age

:Banjarsari $30 \quad$ I| Banjarsari 5 Banjarsari 8

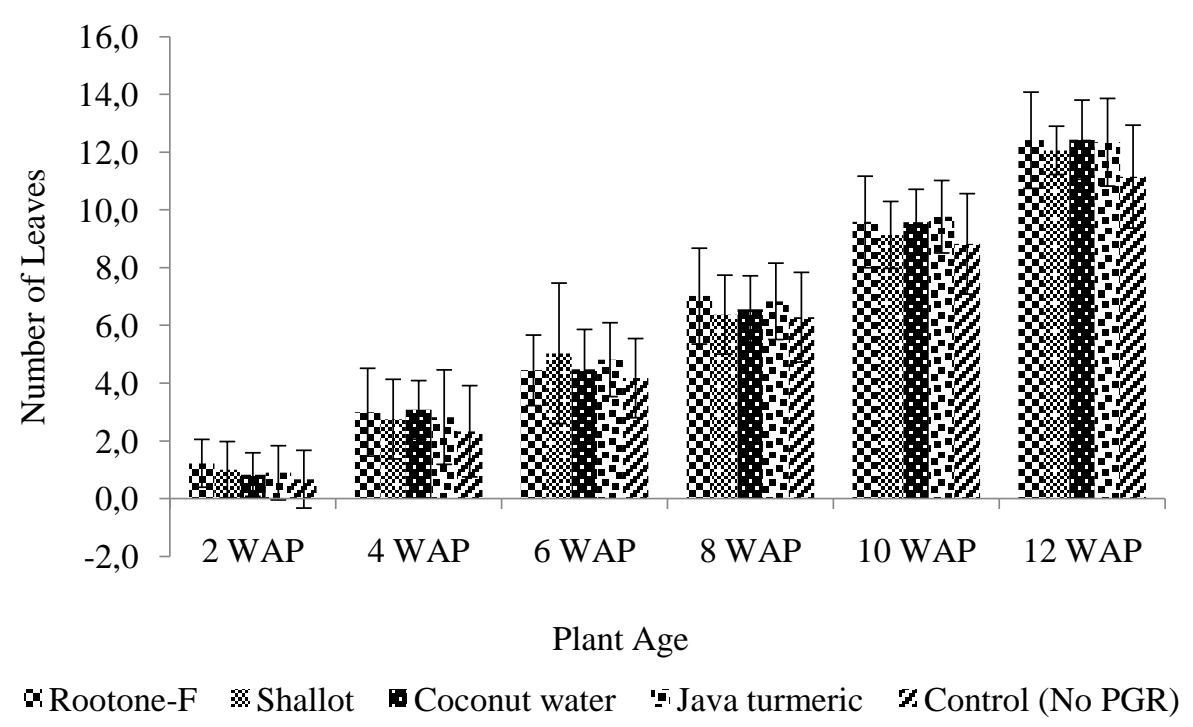

Figure 1 - Number of leaves of the Prabu Bestari grapevine seedling affected by different rootstocks and PGR WAP: Weeks After Planting

Without the growth regulators, Prabu Bestari grapevine seedling with Banjarsari 30, Banjarsari 5, and Banjarsari 8 rootstock had shoot with diameters of 3.12, 3.58, and $3.67 \mathrm{~mm}$ respectively on 12 WAP. With application of the growth regulators, the shoot diameters on 12 WAP were $3.55,3.59$, and 3.55 consecutively (Figure 2). The findings are at the opposite of Köse et al., (2014) and Somkuwar et al. (2014; 2015)'s that certain type of rootstocks increase grapevine diameter. Bidabadi et al. (2018) reported that combination between auxin and cytokinin increase rootstock diameter.

At the end of the experiment, application of growth regulator increase number of roots as well as length and weight of the roots. Rootone- $F$, shallot extract and coconut water enable seedling roots to grow longer compared to those without any growth regulator application. Java turmeric extract cannot increase number, length and weight of Prabu Bestari seedling roots (Table 4). 


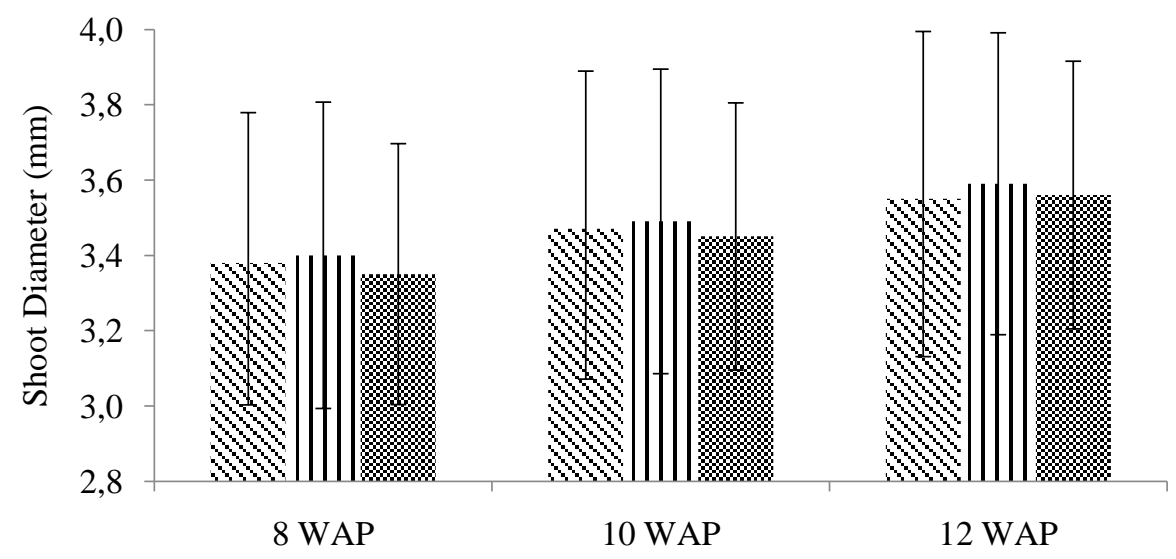

Plant Age
s Banjarsari 30
I | Banjarsari 5
Banjarsari 8

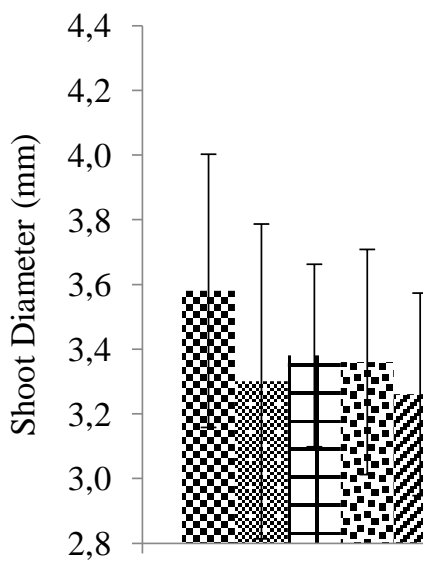

8 WAP

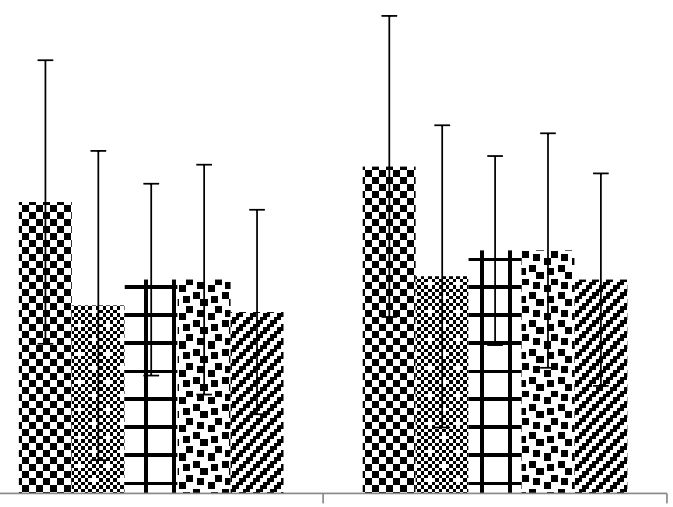

10 WAP

12 WAP

Plant Age

Q Rootone-F Shallot $\vdash$ Coconut water $a$ Java turmeric $z$ Control (No PGR)

Figure 2 - Shoot diameter of Prabu Bestari grapevine seedling affected by different rootstocks and PGR WAP: Weeks After Planting

Table 4 - Characteristics of Prabu Bestari grapevine roots with different rootstocks and PGR

\begin{tabular}{llll}
\hline Treatment & Number of Roots & Root Length $(\mathrm{cm})$ & Root Weight $(\mathrm{g})$ \\
\hline Rootstocks & & & \\
Banjarsari 30 & $28.01 \pm 7.56$ & $25.04 \pm 7.23$ & $15.05 \pm 3.65$ \\
Banjarsari 5 & $26.03 \pm 6.20$ & $25.63 \pm 4.06$ & $14.50 \pm 2.78$ \\
Banjarsari 8 & $27.41 \pm 4.75$ & $23.14 \pm 4.78$ & $15.01 \pm 4.38$ \\
PGR & & & $16.45 \pm 4.49 \mathrm{a}$ \\
Rootone-F & $29.83 \pm 6.41 \mathrm{a}$ & $26.93 \pm 6.25 \mathrm{ab}$ & $16.01 \pm 4.45 \mathrm{a}$ \\
Shallot & $29.63 \pm 7.90 \mathrm{a}$ & $28.41 \pm 5.77 \mathrm{a}$ & $16.05 \pm 2.33 \mathrm{a}$ \\
Coconut water & $29.82 \pm 4.61 \mathrm{a}$ & $25.32 \pm 2.74 \mathrm{ab}$ & $14.04 \pm 1.47 \mathrm{ab}$ \\
Java turmeric & $24.68 \pm 4.24 \mathrm{ab}$ & $22.88 \pm 3.92 \mathrm{bc}$ & $11.72 \pm 2.33 \mathrm{~b}$ \\
Control (No PGR) & $21.78 \pm 2.32 \mathrm{~b}$ & $19.47 \pm 3.91 \mathrm{c}$ & $\mathrm{ns}$ \\
\hline Interaction & $\mathrm{ns}$ & $\mathrm{ns}$ &
\end{tabular}

Description: Values followed by the same letter at the same column were not significantly different based on DMRT with $95 \%$ level of confidence; ns: not significant. 


\section{DISCUSSION OF RESULTS}

Suitable rootstocks increase plant response towards biotic and abiotic stress (Toumi et al., 2007; Somkuwar et al., 2014). Rootstocks connect the upper stem and the soil and also influence their connection. Strong and disease-resistant rootstocks can support shoot growth and increase yield (Pulko et al., 2012; Aly et al., 2015). It is reported that growth hormone can influence growth of seeds and flowering (Khurshid et al., 1992), increase production (Kassem et al., 2011), and improve quality of fruits (Ovadia et al., 2013; Dimovska et al., 2014). Rootone-F is a synthetic growth regulator which consists of IBA and NAA as the active ingredients and is categorized as auxin hormone. Shallot extract contains auxin and a little cytokinin, gibberellins and abscisic acid (Okukpe et al., 2012) while coconut water contains phytohormone of, based on the highest to the lowest concentration, auxin, gibberellin, abscisic acid and cytokinin (Tan et al., 2014).

Once the rootstocks touched the upper stem, the cambial area conducts meristematic activity that produces callus and parenchymal tissue which fills space between the rootstocks and upper stem (Wang and Kollmann, 1996). Higher percentage of successful grafting may be due to actively-developed meristem stage in both the rootstocks and the shoot, forming callus. Vascular connection between the rootstocks and the shoot can determine water and nutrients translocation, influence other physiological characteristics, and increase successful rate of grafting (Martínez-Ballesta et al., 2010; Vršič et al., 2015). Bidabadi et al. (2018) combined auxin and cytokinin to increase callus formation in grapevine cuttings. Köse and Güleryüz (2006) reported that auxin application reduced growth rate of grapevine cuttings while, cytokinin increased callus formation in the area where the rootstocks and the shoot met. Auxin was unable to increase callus formation and therefore, decreasing the growth of plant. In this study, application of plant growth regulator is done to promote growth of the grapevine roots and then support growth of the upper stem.

Bud burst is influenced by nutrients in the shoot that act as supply and help the shoot growing more particularly in the early stage of its growth (El-Gendy, 2013; Somkuwar et al., 2015). Findings of Aly et al. (2015) who studied Flame seedless, Superior seedless, and Thompson seedless grapes are in line with this study in which different rootstocks did not have any influence towards the bud burst.

Grapevine seed growth is different depending on the level of callus and roots development, as well as rootstock genotype. Genetically, characteristics of rootstock have influence towards vegetative growth through root distribution, water efficiency and nutrient uptake (Basheer-Salimia dan Hamdan, 2009). Çelik (2000) explained that length of upper stem shoot determines quality of the grafting process and quality of grafted seedling. Application of auxin and cytokinin increase the shoot length of Asgari seedless grapevine (Bidabadi et al., 2018). Java turmeric extract, coconut water and control treatments produced grapevine shoot of the same length. In contrast to the findings of this study, coconut water increased the shoot length of Alphonso Lavalle grapevine (Wahyuningtyas et al., 2017) while shallot extract did not have influence towards the shoot length of grapevines (Utami et al., 2016).

Hifny et al. (2016)'s study is in line with the study where rootstocks did not have any influence towards number of leaves. Nevertheless, Mahmoudzadeh (2015) and Somkuwar et al. (2015) reported that rootstocks increased number of leaves and leaf surface area. Coconut water and shallot can increase number of grapevine seedlings leaves (Diana, 2014; Wahyuningtyas et al., 2017).

Auxin plays a role in cell lengthening and division. It is also used to stimulate rooting quickly and productively in various types of cuttings, for example woody plants, shrubs and bushes (Rademacher, 2015; Bisht et al., 2018). Shallot and coconut water increased number and length of grapevine roots (Diana, 2014; Wahyuningtyas et al., 2017). Application of IBA and NAA also increased quality of grapevine roots (Köse and Güleryüz, 2006). 
In conclusion, Banjarsari 30 as rootstocks and Rootone- $F$ as growth regulator increased grapevine seedling var. Prabu Bestari's growth. Java turmeric extract was unable to promote the growth of the grapevine seedling var. Prabu Bestari's growth.

\section{ACKNOWLEDGMENTS}

The authors would like to thank Mr. Sukadi, a technician at Indonesian Citrus and Subtropical Fruits Research Institute for his assistance during data collection and technical plant management.

\section{CONFLICT OF INTERESTS}

The authors report no conflict of interests.

\section{REFERENCES}

1. Aly, M. A., Ezz, T. M., Harhash, M. M., El-Shenawe, S. E., \& Shehata, A. (2015). Performance of some table grape cultivars grafting on different rootstocks in El-Nubaria region. Asian Journal of Crop Science, 7(4), 256-266. https://doi.org/10.3923/ajcs.2015.256.266.

2. Andrini, A. (2006). Anggur Prabu Bestari Si Merah yang Menggoda. Iptek Hortikultura, 2, 711.

3. Basheer-Salimia, R., \& Hamdan, A.-J. (2009). Assessment of Preliminary Grafting Compatibility-Incompatibility between Local Palestinian Table-Grapevine Cultivars and Different Phylloxera. An-Najah University Journal for Research (N. Sc.), 23, 49-71.

4. Bidabadi, S. S., Afazel, M., \& Sabbatini, P. (2018). Iranian Grapevine Rootstocks and Hormonal Effects on Graft Union, Growth and Antioxidant Responses of Asgari Seedless Grape. Horticultural Plant Journal, 4(1), 16-23. https://doi.org/10.1016/j.hpj.2017.11.002.

5. Bisht, T. S., Rawat, L., Chakraborty, B., \& Yadav, V. (2018). A Recent Advances in Use of Plant Growth Regulators (PGRs) in Fruit Crops - A Review. International Journal of Current Microbiology and Applied Sciences, 7(05), 1307-1336. https://doi.org/10.20546/ijcmas.2018.705.159.

6. Çelik, Ü. (2000). The effects of different grafting methods applied by manual grafting units on grafting success in grapevines. Turkish Journal of Agriculture and Forestry, 24(4), 499-504.

7. Diana, S. (2014). Respon Pertumbuhan Setek Anggur (Vitis vinifera L.) terhadap Pemberian Ekstrak Bawang Merah (Allium cepa L.). Klorofil, 9(2), 50-53.

8. Dimovska, V., Petropulos, V. I., Salamovska, A., \& Ilieva, F. (2014). Flame Seedless Grape Variety and Different Concentration of Gibberellic Acid. Bulgarian Journal of Agricultural Science, 20(1), 127-132.

9. El-Gendy, R. S. S. (2013). Evaluation of Flame Seedless Grapevines Grafted on Some Rootstocks. Journal of Horticultural Science and Ornamental Plants, 5(1), 1-11.

10. Hifny, H. A., Baghdady, G. A., Abdrabboh, G. A., Sulta, M. Z., \& Shahda, M. A. (2016). Effect of Rootstocks on Growth, Yield and fruit quality of Red Globe grape. Annals of Agricultural Science Moshtohor, 54(2), 339-344.

11. Kassem, H. A., Al-Obeed, R. S., \& Soliman, S. S. (2011). Improving Yield, Quality and Profitability of Flame Seedless Grapevine Grown Under Aird Environmental by Growth Regulators Preharvest Applications. Middle-East Journal of Scientific Research, 8(1), 165172.

12. Khurshid, T., Jackson, D. I., \& Rowe, R. N. (1992). Effect of plant growth regulators on flower development in the grapevine (Vitis vinifera L.) cv. Cabernet Sauvignon. New Zealand Journal of Crop and Horticultural Science, 20(3), 351-356. 
https://doi.org/10.1080/01140671.1992.10421778.

13. Kim, M. K., Choi, G. J., \& Lee, H. S. (2003). Fungicidal Property of Curcuma longa L. Rhizome-Derived Curcumin against Phytopathogenic Fungi in a Greenhouse. Journal of Agricultural and Food Chemistry, 51(6), 1578-1581. https://doi.org/10.1021/jf0210369

14. Köse, B., Karabulut, B., \& Ceylan, K. (2014). Effect of rootstock on grafted grapevine quality. European Journal of Horticultural Science, 79(4), 197-202.

15. Köse, C., \& Güleryüz, M. (2006). Effects of auxins and cytokinins on graft union of grapevine (Vitis vinifera). New Zealand Journal of Crop and Horticultural Science, 34(2), 145-150. https://doi.org/10.1080/01140671.2006.9514399.

16. Krismawati, A., \& Prahardini, P. (2011). Karakteristik dan Keunggulan Anggur Varietas "Red Pince" (Prabu Bestari) dan "Cardinal" (Probolinggo Super) di Kota Probolinggo. El-Hayah, 2(1), 47-55.

17. Kurniati, F., Sudartini, T., \& Hidayat, D. (2017). Aplikasi Berbagai Bahan ZPT Alami untuk Meningkatkan Pertumbuhan Bibit Kemiri Sunan (Reutealis trisperma (Blanco) Airy Shaw). Jurnal Agro, 4(1), 40-49. https://doi.org/10.15575/1307.

18. Leovici, H., Kastono, D., \& Putra, E. T. S. (2014). Pengaruh Macam dan Konsentrasi Bahan Organik Sumber Zat Pengatur Tumbuh Alami terhadap Pertumbuhan Awal Tebu (Saccharum officinarum L.). Vegetalika, 3(1), 22-34. https://doi.org/10.22146/veg.4012.

19. Mahmoudzadeh, H. (2015). The Effects of Crown Gall Resistant Rootstocks on the Growth, Yield, and Fruit Quality of Thompson Seedless Grapevine (Vitis vinifera L.) cv. International Journal of Current Research in Biosciences and Plant Biology, 2(10), 1-8.

20. Martínez-Ballesta, M. C., Alcaraz-López, C., Muries, B., Mota-Cadenas, C., \& Carvajal, M. (2010). Physiological aspects of rootstock-scion interactions. Scientia Horticulturae, 127(2), 112-118. https://doi.org/10.1016/j.scienta.2010.08.002.

21. Maulidah, S., \& Pratiwi, D. E. (2010). Analisis Kelayakan Finansial Usahatani Anggur Prabu Bestari. Agrise, X(3), 213-225.

22. Okukpe, K. M., Adeloye, A. A., Belewu, M. A., Alli, O. I., Adeyina, O. A., \& Annongu, A. A. (2012). Investigation of Phytohormonal Potential of Some Selected Tropical Plants. Research Journal of Medicinal Plant, 6(6), 425-432. https://doi.org/10.3923/rjmp.2012.425.432.

23. Ovadia, R., Oren-Shamir, M., Kaplunov, T., Zutahy, Y., Lichter, A., \& Lurie, S. (2013). Effects of plant growth regulators and high temperature on colour development in 'Crimson Seedless' grapes. The Journal of Horticultural Science and Biotechnology, 88(4), 387-392. https://doi.org/10.1080/14620316.2013.11512980.

24. Pulko, B., Vršič, S., \& Valdhuber, J. (2012). Influence of various rootstocks on the yield and grape composition of Sauvignon Blanc. Czech Journal of Food Sciences, 30(5), 467-473. https://doi.org/10.17221/347/2011-CJFS.

25. Rademacher, W. (2015). Plant Growth Regulators: Backgrounds and Uses in Plant Production. Journal of Plant Growth Regulation, 34(4), 845-872. https://doi.org/10.1007/s00344-015-9541-6.

26. Sharma, G. (2015). Review of Plant Growth Regulators - Control Growth, Development and Movement. International Journal of Preclinical \& Pharmaceutical Research, 6(3), 155-159.

27. Somkuwar, R. G., Jogaiah, S., Sawant, S. D., Taware, P. B., Bondage, D. D., \& Itroutwar, P. (2014). Rootstocks Influence the Growth, Biochemical Contents and Disease Incidence in Thompson Seedless Grapevines. British Journal of Applied Science and Technology, 4(6), 1030-1041.

28. Somkuwar, R. G., Taware, P. B., Bhange, M. A., Sharma, J., \& Khan, I. (2015). Influence of Different Rootstocks on Growth, Photosynthesis, Biochemical Composition, and Nutrient Contents in 'Fantasy Seedless' Grapes. International Journal of Fruit Science, 15(3), 251266. https://doi.org/10.1080/15538362.2015.1031564.

29. Sudjijo. (2009). Pengaruh Ukuran Batang Bawah dan Batang Atas terhadap Pertumbuhan 
Durian Monthong, Hepe, dan DCK-01. Jurnal Hortikultura, 19(1), 89-94.

30. Sugiyatno, A. (2017). Perbanyakan Tanaman Anggur dengan Stek-Sambung (Stekbung). Iptek Hortikultura, 13, 7-10.

31. Tan, S., Yong, J., \& Ge, L. (2014). Analyses of Phytohormones in Coconut (Cocos nucifera L.) Water Using Capillary Electrophoresis-Tandem Mass Spectrometry. Chromatography, 1(4), 211-226. https://doi.org/10.3390/chromatography1040211.

32. Toumi, I., M'Sehli, W., Bourgou, S., Jallouli, N., Bensalem-Fnayou, A., Ghorbel, A., \& Mliki, A. (2007). Response of ungrafted and grafted grapevine cultivans and rootstocks (Vitis sp.) to water stress. OENO One, 41(2), 85. https://doi.org/10.20870/oeno-one.2007.41.2.853.

33. Upendra, R. ., Khandelwal, P., \& Reddy, A. H. . (2011). Turmeric powder (Curcuma longa Linn.) as an antifungal agent in plant tissue culture studies. International Journal of Engineering Science and Technology, 3(11), 7899-7904.

34. Utami, T., Hermansyah, \& Handajaningsih, M. (2016). Respon Pertumbuhan Stek Anggur (Vitis vinifera L.) terhadap Pemberian Beberapa Konsentrasi Ekstrak Bawang Merah (Allium ascalonicum L.). Akta Agrosia, 19(1), 20-27.

35. Vršič, S., Pulko, B., \& Kocsis, L. (2015). Factors influencing grafting success and compatibility of grape rootstocks. Scientia Horticulturae, 181, 168-173. https://doi.org/10.1016/j.scienta.2014.10.058.

36. Wahyuningtyas, B., Sitawati, \& Aini, N. (2017). Pengaruh Jenis Zat Pengatur Tumbuh terhadap Pertumbuhan 3 Varietas Anggur (Vitis vinifera L.) Hasil Stek Cabang. Jurnal Produksi Tanaman, 5(6), 965-970.

37. Wang, Y., \& Kollmann, R. (1996). Vascular Differentiation in the Graft Union of in-vitro Grafts with Different Compatibility. - Structural and Functional Aspects. Journal of Plant Physiology, 147(5), 521-533. https://doi.org/10.1016/S0176-1617(96)80041-1. 